Journal of Environmental Science and Sustainable Development

Volume 4

Issue 2 December

Article 5

$12-31-2021$

\title{
FLOOD ANALYSIS AND HYDRAULIC COMPETENCE OF DRAINAGE STRUCTURES ALONG ADDIS ABABA LIGHT RAIL TRANSIT
}

\author{
Moses Kiwanuka \\ Department of Civil Engineering, Ndejje University, P. O. Box 7088, Kampala, Uganda and Department of \\ Civil Engineering, Addis Ababa Institute of Technology, P.O.Box 385 Addis Ababa, Ethiopia, \\ moseskiwanukaldp14@gmail.com \\ Seleshi Yilma \\ Department of Civil engineering, Addis Ababa Institute of Technology, P.O.Box 385 Addis Ababa, Ethiopia, \\ yilma.seleshi@gmail.com \\ Joel Webster Mbujje \\ Department of Civil engineering, Kabale University, P. 0. 317, Kabale, Uganda, mbujje@gmail.com \\ John Bosco Niyomukiza \\ Department of Civil Engineering, Ndejje University, P. O. Box 7088, Kampala, Uganda and Department of \\ Civil Engineering, Diponegoro University, P. O. Box 50275, Semarang, Indonesia, niyojayb1992@gmail.com
}

Follow this and additional works at: https://scholarhub.ui.ac.id/jessd

Part of the Electrical and Electronics Commons, Life Sciences Commons, and the Social and Behavioral Sciences Commons

\section{Recommended Citation}

Kiwanuka, Moses; Yilma, Seleshi; Mbujje, Joel Webster; and Niyomukiza, John Bosco (2021). FLOOD ANALYSIS AND HYDRAULIC COMPETENCE OF DRAINAGE STRUCTURES ALONG ADDIS ABABA LIGHT RAIL TRANSIT. Journal of Environmental Science and Sustainable Development, 4(2), 248-272. Available at: https://doi.org/10.7454/jessd.v4i2.1122

This Original Research Article is brought to you for free and open access by the School of Environmental Science at UI Scholars Hub. It has been accepted for inclusion in Journal of Environmental Science and Sustainable Development by an authorized editor of UI Scholars Hub. 


\title{
FLOOD ANALYSIS AND HYDRAULIC COMPETENCE OF DRAINAGE STRUCTURES ALONG ADDIS ABABA LIGHT RAIL TRANSIT
}

\author{
Moses Kiwanuka ${ }^{1,2 *}$, Seleshi Yilma ${ }^{2}$, Joel Webster Mbujje ${ }^{3}$, John Bosco Niyomukiza ${ }^{1,4}$ \\ ${ }^{1}$ Department of Civil Engineering, Ndejje University, P. O. Box 7088, Kampala, Uganda \\ ${ }^{2}$ Department of Civil Engineering, Addis Ababa Institute of Technology, P.O.Box 385 Addis \\ Ababa, Ethiopia \\ ${ }^{3}$ Department of Civil Engineering, Kabale University, P. O. 317, Kabale, Uganda \\ ${ }^{4}$ Department of Civil Engineering, Diponegoro University, P. O. Box 50275, Semarang, \\ Indonesia
}

*Corresponding author: moseskiwanukaldp14@gmail.com

(Received: 6 September 2020; Accepted: 7 November 2021; Published: 30 December 2021)

\begin{abstract}
The occurrence of flooding events and the associated risks are increasing in the urban areas of most developing countries. Flooding in any circumstance causes major stresses on affected area's economic, social and environmental regimes. Therefore, the current study presents a flood analysis and hydraulic competence of existing drainage structures on some selected roads of Addis Ababa City, after integration with Addis Ababa Light Rail Transit (AALRT) Drainage Systems. The existing side drains and cross drainage structures located within the study area were inspected and assessed to ascertain different aspects relating to their performance. Different watersheds were delineated. Hydrological analysis was then carried out using Geospatial tools such as ARCGIS, ARCSWAT, and HEC GEOHMS to determine the different watersheds contributing to the flows. The flows were obtained from the rational method for areas less than $0.5 \mathrm{~km} 2$ and HEC HMS for areas greater than $0.5 \mathrm{~km} 2$. The hydraulic analysis was carried out using HY-8 for the culvert and the Hydraulic toolbox for side drains. It was found from field surveys and measurements that the existing side drain of $900 \mathrm{~mm}$ circular pipe could not convey the maximum flow. The existing box culvert, which comprised of one barrel was able to convey the design flow of $29.52 \mathrm{~m} 3 / \mathrm{s}$ with a headwater elevation of $2300.94 \mathrm{~m}$. The existing box culvert was sufficient in conveying the designed flow since its headwater elevation was lower than that of the roadway elevation. However, observations like the presence of accumulated silt, debris within most side drains, and an undersized side drain reduced its hydraulic competence. The undersized side drain was redesigned by increasing its diameter to $1200 \mathrm{~mm}$. The study acts as a yardstick for drainage assessment, especially for existing structures, an indicator for identifying the most flood-prone areas along the railway track. It recommended an intermediate cross culvert before Lancha, regular desilting, and putting screens at inlets of side drains and some distance before the entrance of the culverts. Periodic maintenance of the existing drainage structures and widening of the pipe conduits for the side drains to about $1200 \mathrm{~mm}$ for easy maintenance is also necessary.
\end{abstract}

Keywords: Box culverts; Design flow; Drainage structures; Flood; Hydraulic toolbox. 


\section{Introduction}

Recently, the rate of flooding in urban areas is unpredictable (Nkwunonwo et al., 2020). Over the past decades, the global urban flood intensity has increased drastically, and the primary factors for the cause are climate change and urbanization (Berndtsson et al., 2019; SemadeniDavies et al., 2008). Climate change is considered a significant factor that increases flood risk, resulting in increased frequency and intensity of torrential storms (IPCC, 2007). According to Berndtsson et al. (2019), a warmer climate leads to frequent precipitation events, thus leading to flooding. Another significant contributor to flooding is urbanization. As urbanization increases, runoff also increases, including reduced rainwater infiltration due to impermeable surfaces such as asphalt (asphalt, and concrete) surfaces, roads, parking lots, and buildings leading to increased intakes for drainage structures resulting in lower infiltration rates (EPA, 2003; Sriyana et al., 2020).

Flooding leads to economic, social, and environmental losses to the affected areas. Different studies have addressed the negative impacts of flooding such as the flash flooding event that occurred in Newcastle in 2012 displaced more than 1200 homes, and £8m of direct damage to roads and pavements alone (Pregnolato et al., 2017). According to Hasan et al. (2019), the increased runoff could not be easily conveyed by the incapacitated drainage systems thus leading to continuous flooding, which leads to the destruction of property, infrastructure, lives and acts as a barrier to economic development. These floods usually destroy properties including houses even personal belongings and the loss of lives for extreme cases. An increase in population causes urban development, thus leading to changes in land use and land cover (Adeloye \& Rustum, 2011; Arrighi et al., 2019; Hasan et al., 2019). This is because people are changing floodplains to industrial and residential use.

However, within urbanized areas, the paved and other impervious surfaces hinder the capacity of the soil to absorb water. As a result of urbanization, there is an increment in the runoff velocity resulting in greater water volumes on the surface, leading to peak discharges (EPA, 2003). Despite these flooding negative impacts, management measures are still lacking in developing countries (Nkwunonwo et al., 2020). Therefore, there is a need to develop measures that will mitigate the occurrence of flooding. Mitigating flooding issues require appropriate urban drainage designs and integrated watershed management approaches (Sriyana et al., 2020). Urban drainage systems play a vital role in collecting and conveying stormwater 
and wastewater away from urban areas. The national and local governments have been implementing structural measures, constructing flood-control reservoirs and infiltration and storage facilities using the available funds for flood prevention. Significant non-structural measures must also be employed to reduce flood risk using such tools as hazard maps and effective forecasting systems. Flood insurance mitigates flood inundation damage and contributes to relieving flood risk. For urban flood risk management, these factors should be compared and evaluated in the decision-making process. There are many different definitions of flood risk. Risk evaluation can be performed quantitatively (Salunkhe et al., 2018).

The risk of a hazardous event generally is quantified by multiplying its probability of occurrence by its impact. However, "Crichton Risk Triangle" gives a simple, comprehensive definition that consists of hazard, vulnerability, and exposure for flood risk (Crichton, 2008). Some researchers often adopt a narrow definition of flood risk, which refers to the probability of failure during a flood event (National Research Council, 2000) while others strongly emphasize the psychological aspect of flood risk. However, flood risk can be described as an evaluation of the combination of the probability of flooding and the adverse consequences that may arise (Klijn et al., 2008). There is a standard definition of flood risk as to the "product" of the probability of floods and their consequences (Klijn et al., 2008). This definition enables us to evaluate flood risk on a monetary basis. The evaluation will focus on the flood analysis on the frequency and severity of flooding events (Davis, 2003; Morita, 2008).

The structure of the newly built AALRT track is made of ballast without a drainage system so that it uses an integrated system with the existing highway. This results in floods, especially in the low-lying areas of Lancha. The existing drainage system could not accommodate the entire runoff. Studies have shown that inappropriate drainage design and heavy rains could lead to flooding issues (Gülbaz \& Kazezy1lmaz-Alhan, 2017; Hasan et al., 2019). The current study attempts to ascertain the flood analysis and hydraulic competence of the existing drainage system of existing drainage structures on some selected roads of Addis Ababa City, Ethiopia after integration with Addis Ababa Light Rail Transit (AALRT) Drainage Systems. However, the study was limited to only as-built data, especially for hydraulic structures. This is because the researcher had no access to the design reports from the responsible offices. 


\section{Methods}

\subsection{Study Area}

The case study area is located in Addis Ababa city, one of the oldest and largest cities in Africa established by Emperor Menilik II in 1886. It is found at $8^{\circ} 50^{\prime} 11^{\prime \prime}-9^{\circ} 05^{\prime} 29^{\prime \prime} \mathrm{N}$ and $38^{\circ} 39^{\prime} 40^{\prime \prime}-$ $38^{\circ} 54^{\prime} 57^{\prime}$ 'E on Universal Transverse Mercator (UTM) projection. The population projection of Addis Ababa for all regions at woreda levels from 2014 - 2017 was carried out by the Central Statistical Agency (CSA) and approximated to be 3.3 million (CSA, 2013). The case study route selected is Mesualekia-Nefas Silk2 Route Section. It is found in the south of Addis Ababa within Nefas Silk lafto sub-city area, as shown in Figure 1. The route is between Mesualekia station at a latitude of $9^{\circ} 0$ ' 17.9136 " and $38^{\circ} 45^{\prime} 31.612^{\prime \prime}$ and Nefas- Silk2 station at a latitude $8^{\circ} 58^{\prime} 22.3536^{\prime \prime}$ and longitude of $38^{\circ} 45^{\prime} 38.7^{\prime \prime}$ at an elevation of 2298-2355 mean above sea level (masl) with clay soil as the main soil type.

This is a second highly populated area after the Yeka sub-city (CSA, 2013) with 12 Weredas, 128 Subweredas, 397 Sefers, and 1059 blocks (Alamirew, 2016). Its rapid growth is characterized by commercial and residential buildings causing an increment in the runoff volume. The major socio-economic activities within the sub-city are trading, and manufacturing services with few agricultural activities (Alamirew, 2016). A combined project route location and land use map are shown in Figure 1.

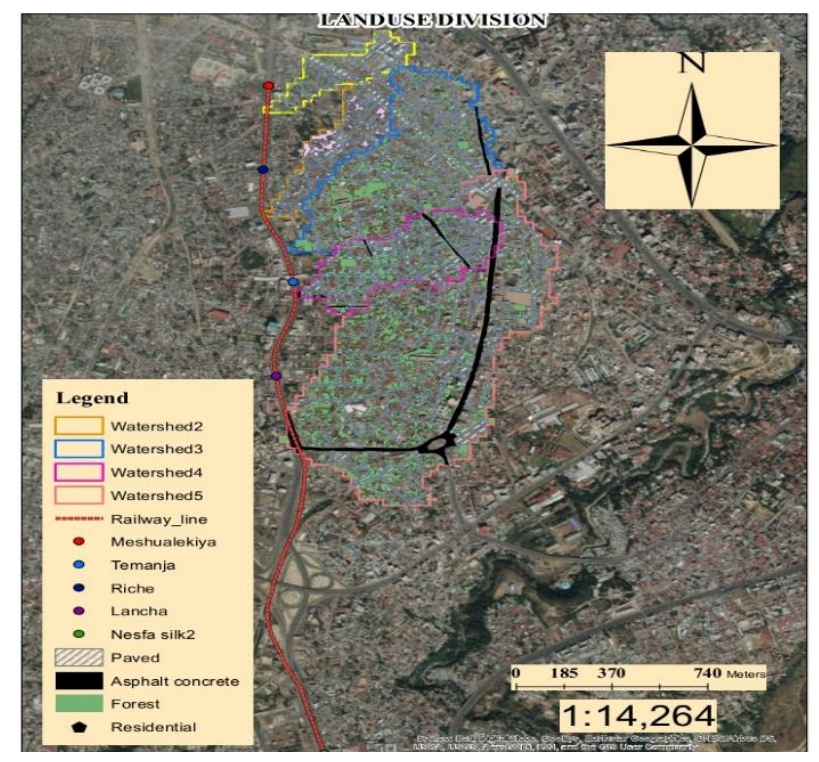

Figure 1. Project route location and land use map 


\subsection{Meteorological data}

Maximum annual daily rainfall data for 50 years, as shown in Table 1, is obtained from the National Meteorology Agency (NMA) of Ethiopia. Using Thiessen's polygon analysis within ArcGIS, Ababa Observatory weather station located at 38 $44^{\prime} 51^{\prime \prime} \mathrm{N}$ and 905'56.076" E was chosen because of its proximity to the study area. There are different meteorological regions which include; A1, A2, A3, A4, B1, B2, C, and D within Ethiopia (Nigussie, 2018). However, the study is in region A2, as shown in Figure 2. Calibration of the HEC-HMS model was done by using observed data for 14 years from Akaki station.

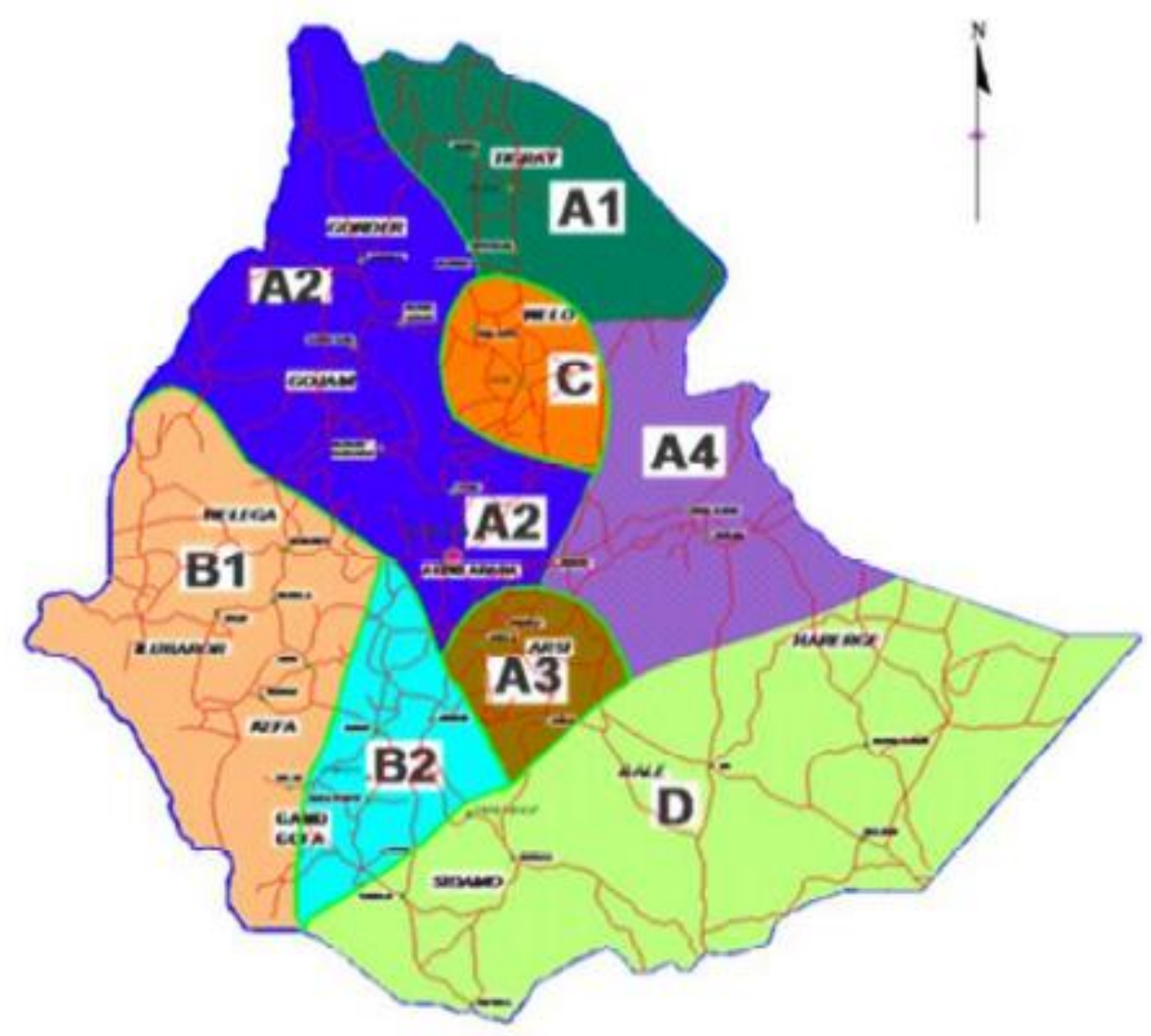

Figure 2. Location of Ethiopian meteorological regions (ERA, 2013)

Table 1. Maximum annual daily precipitation

\begin{tabular}{cccc}
\hline Year & $\begin{array}{c}\text { Maximum daily } \\
\text { precipitation }(\mathrm{mm})\end{array}$ & Year & $\begin{array}{c}\text { Maximum daily } \\
\text { precipitation }(\mathrm{mm})\end{array}$ \\
\hline 1968 & 88.0 & 1993 & 53.5 \\
1969 & 51.0 & 1994 & 57.0 \\
1970 & 87.7 & 1995 & 85.3
\end{tabular}

DOI: https://doi.org/10.7454/jessd.v4i2.1122 


\begin{tabular}{lccc}
\hline Year & $\begin{array}{c}\text { Maximum daily } \\
\text { precipitation }(\mathrm{mm})\end{array}$ & Year & $\begin{array}{c}\text { Maximum daily } \\
\text { precipitation }(\mathrm{mm})\end{array}$ \\
\hline 1971 & 42.1 & 1996 & 67.0 \\
1972 & 25.1 & 1997 & 46.3 \\
1973 & 47.1 & 1998 & 78.3 \\
1974 & 62.5 & 1999 & 37.4 \\
1975 & 28.9 & 2000 & 37.1 \\
1976 & 48.6 & 2001 & 96.3 \\
1977 & 59.4 & 2002 & 29.5 \\
1978 & 93.5 & 2003 & 54.9 \\
1979 & 50.6 & 2004 & 44.2 \\
1980 & 36.3 & 2005 & 58.6 \\
1981 & 58.0 & 2006 & 70.9 \\
1982 & 41.4 & 2007 & 64.0 \\
1983 & 50.1 & 2008 & 53.3 \\
1984 & 55.4 & 2009 & 54.7 \\
1985 & 43.2 & 2010 & 44.6 \\
1986 & 83.8 & 2011 & 55.8 \\
1987 & 56.8 & 2012 & 36.4 \\
1988 & 35.5 & 2013 & 47.2 \\
1989 & 49.2 & 2014 & 65.4 \\
1990 & 39.6 & 2015 & 47.8 \\
1991 & 47.3 & 2016 & 47.7 \\
1992 & 51.4 & 2017 & 50.8 \\
\hline
\end{tabular}

\subsubsection{Intensity-Duration-Frequency (IDF) Curves}

This refers to the graphical representation of rainfall intensity, duration, and frequency. IDF curves are the most effective method for determining the maximum design storm event (ERA, 2013). However, an IDF that had been developed 57 years earlier was used as shown in Figure 3 (ERA, 2013). 


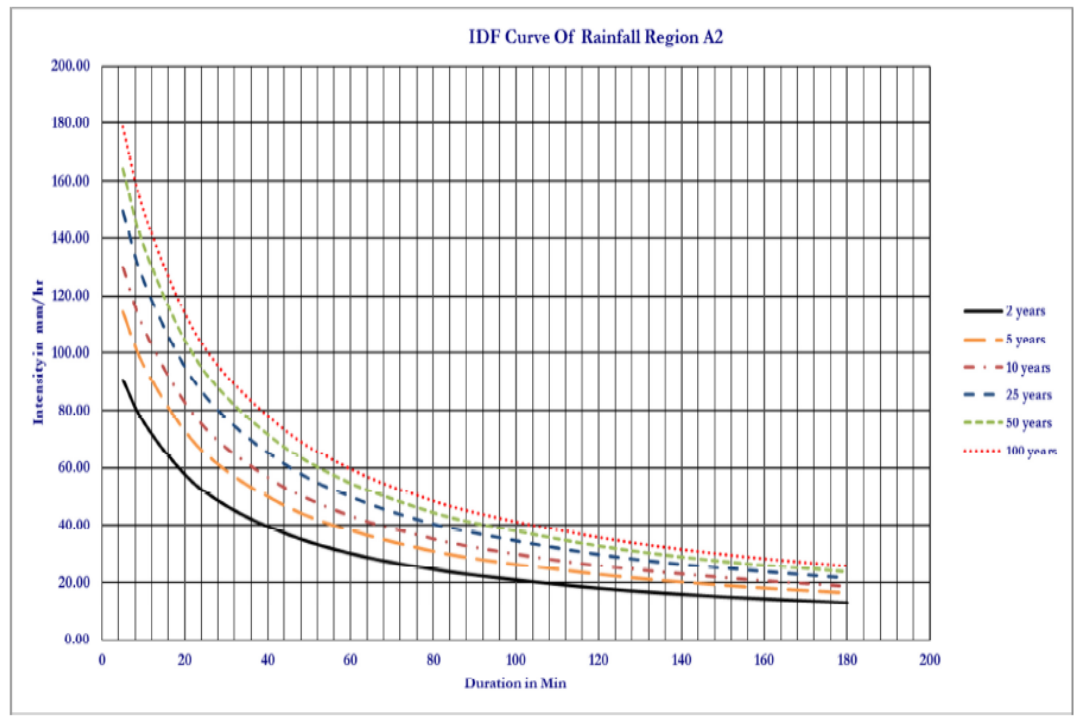

Figure 3. Intensity Duration Frequency curve (ERA, 2013)

\subsubsection{Catchment Area Delineation}

The catchment area in this case refers to the natural area of water flowing towards a particular location, generally located in a river or similar watercourse. Due to limited access to highresolution Digital Elevation Model (DEM) files, a 12.5 m resolution DEM was obtained from the Alaska Satellite Facility website for catchment delineation with all its corresponding properties and natural drainages using HEC GeoHMS, a geospatial hydrology tool kit within ArcGIS v10.4 software. The catchment characteristics vary because of the environment's physical attributes like the topographic and climatic conditions (Kumar et al., 2015).

\subsubsection{Rainfall frequency analysis}

The rainfall frequency analysis was done to determine the peak flows from the delineated catchments. For catchments less than $0.5 \mathrm{~km}^{2}$, a rational method was used while for areas greater than $0.5 \mathrm{~km}^{2}$, an SCS method in HEC-HMS was used. An adjustment of the Rational Method intended for use with major storms was made by multiplying the right side of the rational formula by a frequency factor Cf. The rational formula is shown in Equation 1. However, since the catchment area is small, the peak discharge will be correspondingly small. The smaller the drainage area, the less likely that it will be visited by a high-intensity precipitation event (Conrad et al., 2015). 


\subsubsection{Hydrological Analysis}

During the frequency analysis, different approaches were used to determine the best and appropriate methods for it. According to the Ethiopian Drainage Manual (ERA, 2013,) extreme value type 1 and Log Pearson III are the proposed methods used in frequency analysis. Therefore, as per this study, Log Pearson III was considered for further frequency analysis because of its wide usage in hydrology and high recommendation by U.S. federal agencies (Amin et al., 2016).

$Q=\frac{C_{f} C I A}{360}$

Where; Q- Discharge/ Flow, Cf - Frequency factor, C- Runoff coefficient, I- Rainfall intensity, and A- Area. The first step in the application of HEC-HMS was defining the basin area and sub-basins, a stream network, and diversions and junctions. Under this particular modeling, different methods are embedded within the software, and these include:

1) Transformation method. The Soil Conservation Service (SCS) dimensionless unit hydrograph procedure was used in HEC-HMS as a transformation method. The dimensionless unit hydrograph used by the SCS was developed in the 1950s (Victor, 1971). Its derivation is based on many unit hydrographs from basins that varied in characteristics such as size and geographic location.

2) Loss method. The SCS curve number method was used as a loss method. The right curve number for the catchment of interest was obtained, which defined the runoff potential by basing on the existing land uses and hydrological soil groups. Much care was taken during the selection process of the curve number. The determination of the sub-basin percentage contributing to the land use was specified using the existing land Google earth program and field visits.

3) Routing method. In HEC HMS, different routing methods are embedded in it. However, in this particular catchment, routing wasn't necessary simply because there were no sub-basins.

\subsection{Developing a Hyetograph}

Different hyetographs were developed using an alternating block method for the different return periods of 10, 25, 50 and 100-year rainfall intensity from an IDF curve which acted as 
an input in the modeling software for further analysis. The steps used to obtain the design storm hyetograph were as follows (Chow et al., 1988):

1) Different design return periods were selected.

2) Rainfall intensity was read from an already developed IDF curve corresponding to the calculated time of concentration for the delineated catchment.

3) The corresponding precipitation depth was obtained, $\mathrm{P}$ as the product of the intensity read above and duration from the following Equation 2;

$P=i * T_{d}$

Where; $\mathrm{P}=$ rainfall depth $(\mathrm{mm}), \mathrm{i}=$ intensity from the IDF curve $(\mathrm{mm} / \mathrm{hr})$ and $\mathrm{Td}=$ duration time (hr)

The differences between successive precipitation depths which gave the amount of precipitation to be added for each additional unit of time were obtained. The precipitation increments were recorded into a time sequence with the maximum intensity occurring at the center of the required duration. The remaining precipitation depth is arranged in a descending order alternately to the right and left of the center to obtain the desired design precipitation hyetograph. The hyetographs developed was for watershed 5, which had an area greater than $0.5 \mathrm{~km}^{2}$ for the different return periods of 2, 5, 10, 25, 50, and 100 years. The use of HECHMS software to determine the amount of flow required a design hyetograph. Meanwhile, a rational method was used for obtaining the discharge for the catchments with areas less than $0.5 \mathrm{~km}^{2}$. A TR55 method was used to determine the time of concentration).

\subsection{Calibrated Parameters and Hydrograph}

This process was based on the simulated and observed data for the Akaki station for 14 years. The model parameter calibrated was the curve number. The hydrograph extracted from HECHMS is shown in Figure 4, which shows that both observed and simulated graphs follow the same trends, and the peak flows are close to each other. The hydrographs show that the model adequately captures the peaks as the difference between the simulated and observed peaks was negligible even with slightly underestimating or overestimating some peaks, especially between 11 to 15 January. At the start, the model was warming (the process of simulation before it stabilizes). The rising and recession limbs were captured reasonably well by the 
model. This indicated that the selected parameters and methods were appropriate for the catchment.

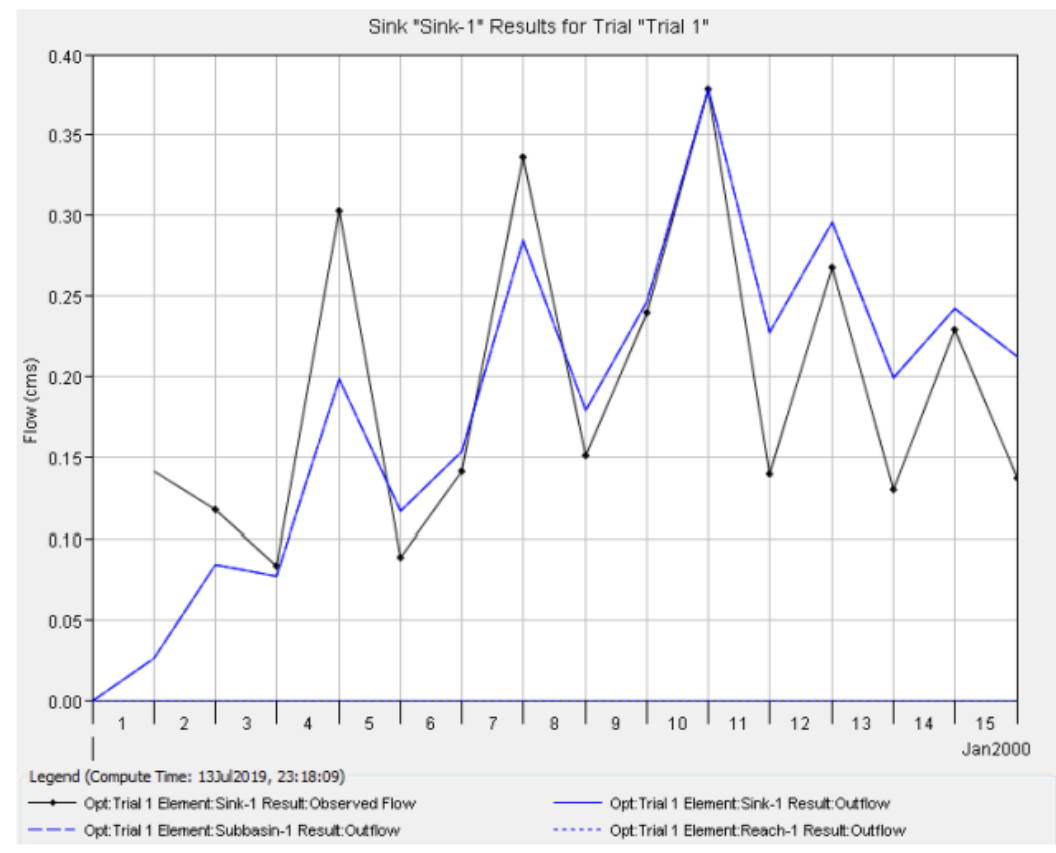

Figure 4. Simulated and observed flow at the outlet (Extract from HEC-HMS)

\subsection{HEC-HMS Model Efficiency}

The model efficiency was assessed using Nash-Sutcliffe (NS) efficiency, and NS was found to be 0.61 (Chanapathi \& Thatikonda, 2020). According to Teklay et al. (2019), the value of NS greater than 0.6 indicates appropriate agreement between simulated and observed data. However, the model slightly overestimated the cumulative volume.

\subsection{Hydraulic modeling}

Since the AALRT had no separate drainage system, the existing system comprised curbopening inlets made of concrete and gullies which acted as collection points for the carriageway runoff. The flow through these pipe conduits ends up in the cross-drainage structure (culvert) at Lancha. A design estimate for the on-track drainage was made given the lack of on-track drainage design reports. The hydraulic toolbox was used to determine the hydraulic competence of the existing off-track side drains while HY-8 was used to analyze the crossculvert performance. 


\subsubsection{Modeling using Hydraulic toolbox}

Field measurements of longitudinal side drains and culverts in the project area were carried out. These measurements aimed to ascertain the dimensions of the existing drainage structures before usage during hydraulic modeling. Since the underground drainage structures may not be accessed during the field visits, the technical design drawings were used to ascertain their structural sizes on and 'as designed' principle of analysis.

\subsubsection{Modelling using HY-8 software}

\subsubsection{Cross drainage structure}

Based on the field survey, there was only one cross drainage structure located at Lancha. Using the measuring tape, the dimensions of the openings were measured and recorded. The existing culvert dimensions were measured and inserted into the software for further analysis. The hydraulic modelling competence of all the existing structures within the case study was done as below.

\subsubsection{On-track drainage system}

This comprised transverse and longitudinal drains used to drain off flow from the track in the shortest time possible to prevent the destruction of other layers. The flow enters the collector pipes and is conveyed by carrier pipes. The transverse drains convey flow from the ballast bed into the longitudinal drains, while the conveyed flow from the longitudinal drains ends up in the municipal stormwater pipe network.

\subsubsection{Transverse aggregate drains}

Based on the calculated on-track flows using the rational methods, it was seen that obtained flows $(0.00154 \mathrm{~m} 3 / \mathrm{s})$ were very minimal; hence aggregate drains were recommended. The optimal size of aggregate drains was sized by computing surface runoff that drains through the ballast using the accumulated runoff. The capacity of the aggregate drains was computed using Darcy's equation, as seen in Equation 3 (ERA, 2013).

$Q_{1}=k * i * A$

Where: $Q 1=$ flow $(\mathrm{m} 3 / \mathrm{s}), \mathrm{k}=$ permeability of the aggregate, $\mathrm{i}=$ hydraulic gradient or slope, and $\mathrm{A}=$ Cross-section area $(\mathrm{m} 2)$. The cross-sectional area used was based on the measured 
surface of the rail trackbed. The permeability of the ballast aggregates from rocks mixed with scoria and Pumice was $0.25 \mathrm{~m} / \mathrm{s}$ corresponding to aggregate sizes ranging between $28 \mathrm{~mm}$ to $37.5 \mathrm{~mm}$ after conducting numerous sieve tests. To size the aggregated drains, Equation 4 was used (ERA, 2013).

$Q_{1}=K * A$

Where; $\mathrm{K}$ is a velocity constant that varies with the slope of the aggregate drain, as shown in Table 2. The two commonly used aggregate sizes are of $20 \mathrm{~mm}$ and $53 \mathrm{~mm}$. The computed Q1 was used for sizing the aggregate drains. The aggregate size used are $20 \mathrm{~mm}$, and its permeability was $0.25 \mathrm{~m} / \mathrm{s}$. Based on the obtained slopes from a google earth elevation profile, a slope of 0.005 was chosen for the drains. From the existing track classes, a track with a design speed of $70 \mathrm{~km} / \mathrm{hr}$ belongs to class 2 as shown in Table 3 hence the consideration for a 25 -year return period design flow.

Table 2. Values of $\mathrm{K}=\mathrm{k}^{*} \mathrm{I}(\mathrm{m} / \mathrm{s})$ for various slopes (ARTC, 2013)

\begin{tabular}{lll}
\hline & \multicolumn{2}{l}{$\mathrm{K}=\mathrm{k} \mathrm{i}(\mathrm{m} / \mathrm{s})$} \\
Slope & $20 \mathrm{~mm}$ & $53 \mathrm{~mm}$ \\
\hline 1 in 100 & 0.00150 & 0.0040 \\
1 in 200 & 0.00075 & 0.0020 \\
1 in 300 & 0.00050 & 0.0013 \\
1 in 400 & 0.00038 & 0.0010 \\
1 in 500 & 0.00030 & 0.0008 \\
\hline
\end{tabular}

Table 3. The typical recurrence interval for various tracks classes (ARTC, 2013)

\begin{tabular}{lc}
\hline Track Class & Recurrence Interval (Years) \\
\hline Class 1 and higher & 50 \\
Class 2 & 25 \\
Class 3 & 10 \\
Class 4 & 5 \\
Class 5 & 5 \\
\hline
\end{tabular}




\subsubsection{Longitudinal drains}

Longitudinal channels measuring $500 \mathrm{~mm}$ by $800 \mathrm{~mm}$ covered by a concrete cover were found throughout the entire stretch of the railway line. The concrete cover in this case helps keep foreign objects, especially solid waste from being disposed into the drains which could have a permanent impact in the long run. Their hydraulic competence was assessed using Hydraulic toolbox. Below are some of the general parameters which were used during the modeling software.

1) Slope, S. An appropriate slope was provided for both side drains and cross drainage structures. The proposed slopes were based on AACRA manual, railway line elevation profile, and ERA drainage manual. The Pavement longitudinal slope of the existing road ranged from 0 to $5.5 \%$ as obtained from the google earth elevation profile. However, the slope adopted for the channel was $4 \%$, and $5 \%$ for the culvert during the analysis in HY-8.

2) Manning's roughness coefficient, $n$. This is defined as a parameter representing the channel roughness and flow resistance. The coefficient of roughness adopted was for concrete. This coefficient affects the flow rate whereby the flow rate decreases as the manning's roughness coefficient increases and vice versa. The factors that affect this coefficient are; cross-sectional geometry and boundary roughness surface roughness, vegetation cover, channel irregularity, channel alignment, size, and shape (Zhu et al., 2020). The adopted manning's value was 0.08 because the channel had light brush and trees and 0.012 for concrete used in HY-8 (ERA, 2013).

3) Design flow. Different design flows corresponding to the different return periods were used for sizing the drainage structures. The design return period was based on the design storm frequency by geometric design criteria (ERA, 2013). For ordinary conditions, storm drains are always sized on the assumption that they will flow full or practically full under the design discharge but will not flow under a pressure head.

\section{Results and Discussions}

The physical characteristics of the catchments were determined by delineating the boundaries with the help of topographic maps. According to Berndtsson et al. (2019), the physical characteristics of catchments are vital in hydrological assessment. In this paper, 
ARCGIS together with embedded software such as ARCSWAT and HEC-GEOHMS were used for catchment delineation. A DEM of $12.5 \mathrm{~m}$ by $12.5 \mathrm{~m}$ for the case study area was selected and used for the delineation. The hydrologic modeling tools in the ArcGIS Spatial Analyst extension toolbox were used for describing the physical components of the DEM.

They were also used in identifying sinks, determining flow direction, calculating flow accumulation, delineating watersheds, and selecting catchment areas. There are five delineated catchments as shown in Figure 5. Each of these catchments contributes to the flow that ends up into the drainage structures. As per this particular case study, the annual maximum precipitation data for 50 years period with a mean of $54.33 \mathrm{~mm}$ and a standard deviation of $16.74 \mathrm{~mm}$ was used.

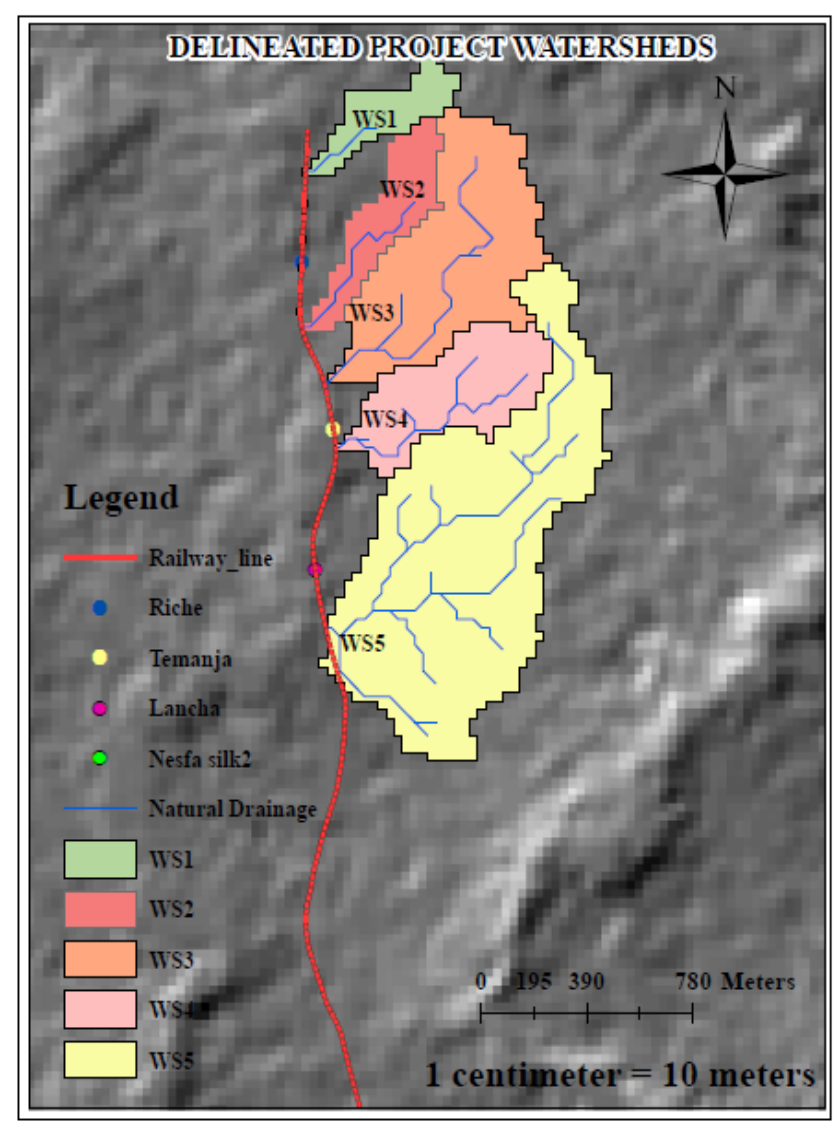

Figure 5. Delineated catchments

\subsection{Rainfall Frequency analysis}

For the rainfall frequency analysis, different approach were used to determine the best and appropriate method. The distribution used included; Extreme value 1, Log Pearson type III, Log-Normal, and Normal distributions. Table 4 above shows that the rainfall depth for DOI: https://doi.org/10.7454/jessd.v4i2.1122 
Extreme value type 1 and Log Pearson III have a slight difference which makes them nearly similar. According to the Ethiopian Drainage manual, Extreme value type 1 and Log Pearson type III are the suggested appropriate methods used in frequency analysis (ERA, 2013). Therefore, as per this study, Log Pearson III was considered for further frequency analysis since it has been widely and frequently used in hydrology. Besides, it is highly recommended by U.S. Federal Agencies (Amin et al., 2016).

Table 4. Calculated rainfall depth.

\begin{tabular}{lllll}
\hline \multicolumn{5}{c}{ Rainfall depth (mm) } \\
\hline ARI (Year) & Extreme value type 1 & Log Pearson type III & Log Normal & Normal \\
\hline 2 & 52 & 52 & 52 & 54 \\
5 & 66 & 67 & 67 & 68 \\
10 & 76 & 76 & 76 & 76 \\
25 & 89 & 88 & 88 & 84 \\
50 & 98 & 97 & 96 & 89 \\
100 & 107 & 106 & 105 & 93 \\
\hline
\end{tabular}

\subsection{Developing a hyetograph}

Different hyetographs were developed using an alternating block method. The hyetographs developed were for watershed 5, which had an area greater than $0.5 \mathrm{~km}^{2}$ for the different return periods of 2, 5, 10, 25, 50, and 100 years. The use of HEC-HMS software to determine the amount of flow required a design hyetograph. Meanwhile, catchments with areas less than 0.5 $\mathrm{km}^{2}$ required a rational method to obtaining the discharge (Tassew et al., 2019). Different values for the time of concentration were calculated using two different methods; for the catchments greater than $0.5 \mathrm{~km}^{2}$, a TR55 method was used while for areas less than $0.5 \mathrm{~km}^{2}$, a Kirprich method was used. The hyetographs developed for catchment 5 is shown in Figure 6. A TR55 method was used to calculate the time of concentration. 


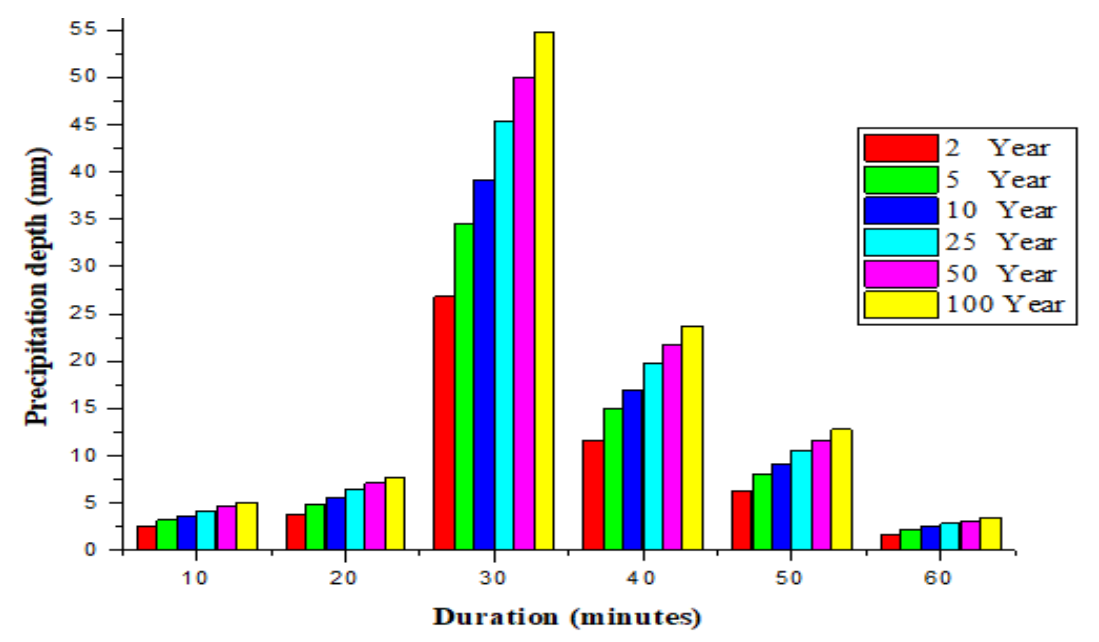

Figure 6. Combined Hyetograph for watershed 5

\subsection{Hydrological modelling}

\subsubsection{Discharge Obtained from Rational Method}

The runoff coefficient, $\mathrm{C}$ was calculated based on; return period, the slope of catchment vegetation, and hydrological soil group. The obtained discharge values are shown in Table 5. It was observed that watershed 3 produced higher discharges than the rest of the other watersheds. This could be attributed to its size. Small drainage areas have a short time of concentration, hence producing high intensity. This consequently leads to a high discharge. The current study agrees with the previous study conducted by Wasko and Sharma (2017) who found that smaller drainage areas are less likely to experience a high-intensity precipitation event.

The different peak flows corresponding to the different ARI imply that those flows of the same magnitude are expected to reoccur after those particular ARIs. For example, the flows corresponding to an ARI of 2 years are expected to reoccur after 2 years. During the hydraulic analysis, the design flow considered corresponded to an ARI of 25 years while a design check was done using the flow corresponding to an ARI of 50 years. 
Table 5. Calculated discharge

\begin{tabular}{ccccc}
\hline $\begin{array}{c}\text { ARI } \\
\text { (Year) }\end{array}$ & Watershed 1 & Watershed 2 & Watershed 3 & Watershed 4 \\
\hline 2 & 1.57 & 1.85 & 3.46 & 1.17 \\
5 & 1.98 & 2.36 & 4.41 & 1.48 \\
10 & 2.15 & 2.63 & 5.11 & 1.71 \\
25 & 2.72 & 3.32 & 6.38 & 2.16 \\
50 & 3.24 & 3.97 & 8.00 & 2.54 \\
\hline
\end{tabular}

\subsubsection{Discharge Obtained from SCS CN Method}

An SCS curve number and other parameters were used in the estimation of the discharge. Most runoff estimation techniques use the size of the watershed as the main factor. However, runoff rates and volumes normally increase with increasing drainage area. The catchment area is in hydrological soil groups B and D with one kind of moisture content i.e. Antecedent Moisture Content (AMC II). The average calculated curve number for watershed 5 was $87.74 \%$ as per generated land use map in Figure 1. Therefore, the higher the $\mathrm{CN}$, the higher the runoff potential. During the hydraulic analysis, the design flow considered corresponded to an ARI of 25 years coreesponding to $24.6 \mathrm{~m}^{3} / \mathrm{s}$ (see Table 6). while a design check was done using the flow corresponding to an ARI of 50 years.

Table 6. Discharge obtained from SCS CN method for Watershed 5

\begin{tabular}{lllll}
\hline ARI (Year) & 2 & 5 & 10 & 25 \\
Discharge $\left(\mathrm{m}^{3} / \mathrm{s}\right)$ & 13.0 & 17.5 & 20.5 & 24.6 \\
\hline
\end{tabular}

\subsection{Hydraulic modelling}

The headwater elevation obtained for the actual design discharge of $29.52 \mathrm{~m} 3 / \mathrm{s}$ is $2300.94 \mathrm{~m}$, as seen in Table 7, which is lower than the roadway elevation. This means that the culvert will be able to convey the design discharge without overtopping the roadway. Normally the roadway overtopping entails culvert headwater elevation is greater than roadway crest (Normann et al., 1985). Based on the water surface profile (see Figure 7) obtained from the software, the prevalent control condition at the design flow is the outlet control. The results 
from HY-8 software reveal that the existing cross drainage structure is sufficient to convey the flow from the upstream to the downstream without overtopping the surface.

However, flooding is still frequently encountered in the low-lying areas of the Lancha station due to uncollected runoff and poor discharge from the study catchment where the side inlet is blocked by sediment (see Figure 8a). In addition, the causes of flooding in this area are the improper cross-slope of the asphalt road which prevents the flow of asphalt sheets from passing to the inlet (Alemu, 2017), the presence of garbage upstream of the cross-drainage structure (see Figure 8b), and downstream of the existing culverts (see Figure 9).

Table 7. Summary of input in HY-8

\begin{tabular}{|c|c|c|c|}
\hline S/No. & Description & Metric & Remark \\
\hline 1 & Design flow & $29.52 \mathrm{~m}^{3} / \mathrm{s}$ & Calculated \\
\hline 2 & Maximum flow & $59.27 \mathrm{~m}^{3} / \mathrm{s}$ & Calculated \\
\hline 3 & Channel type & $\begin{array}{l}\text { Rectangular } \\
\text { channel }\end{array}$ & Observed \\
\hline 4 & Channel slope & 0.004 & Calculated \\
\hline 5 & Channel invert level elevation & $2296.7 \mathrm{~m}$ & $\begin{array}{l}\text { Calculated basing on the } \\
\text { road profile }\end{array}$ \\
\hline 6 & Manning's constant (channel) & 0.08 & ERA, drainage manual \\
\hline 7 & Invert level elevation & $2296.9 \mathrm{~m}$ & $\begin{array}{l}\text { Calculated basing on the } \\
\text { road profile }\end{array}$ \\
\hline 8 & Outer level elevation & $2294.9 \mathrm{~m}$ & $\begin{array}{l}\text { Calculated basing on the } \\
\text { road profile }\end{array}$ \\
\hline 9 & Culvert slope & 0.05 & ERA, drainage manual \\
\hline 10 & Manning's constant (culvert) & 0.012 & ERA, drainage manual \\
\hline 11 & Roadway elevation & $2302 \mathrm{~m}$ & Calculated \\
\hline 12 & Roadway surface & Paved & Observed \\
\hline 13 & Culvert shape & Box & Observed \\
\hline 14 & Material & Concrete & Observed \\
\hline 15 & Culvert length & $28 \mathrm{~m}$ & Same as road width \\
\hline 16 & Top width & $28 \mathrm{~m}$ & AACRA \\
\hline
\end{tabular}




\begin{tabular}{llll}
\hline S/No. & Description & Metric & Remark \\
\hline 17 & Span & $4000 \mathrm{~mm}$ & Measured \\
18 & Rise & $3300 \mathrm{~mm}$ & Measured \\
19 & Bottom width of channel & $7 \mathrm{~m}$ & Measured \\
20 & Crest length & $410 \mathrm{~m}$ & Measured \\
21 & Number of barrels & 1 & Observed \\
22 & Inlet configuration & Square edge $\left(90^{0}\right)$ & Observed \\
23 & Culvert type & Straight & Observed \\
\hline
\end{tabular}

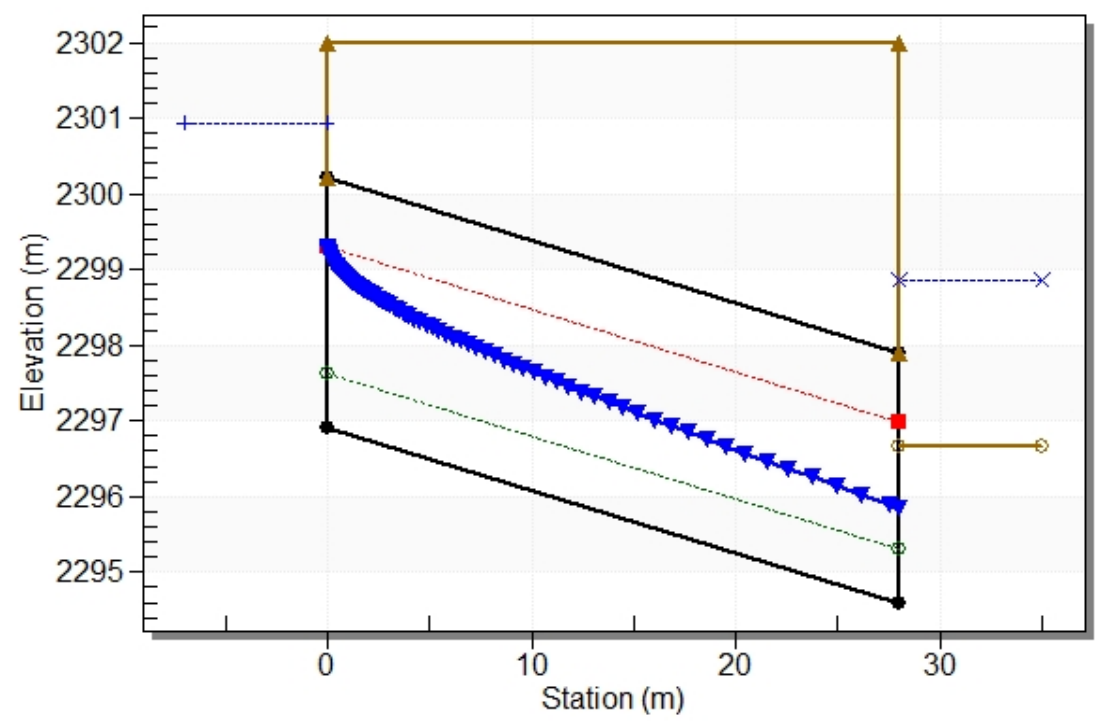

Figure 7. Water surface profile

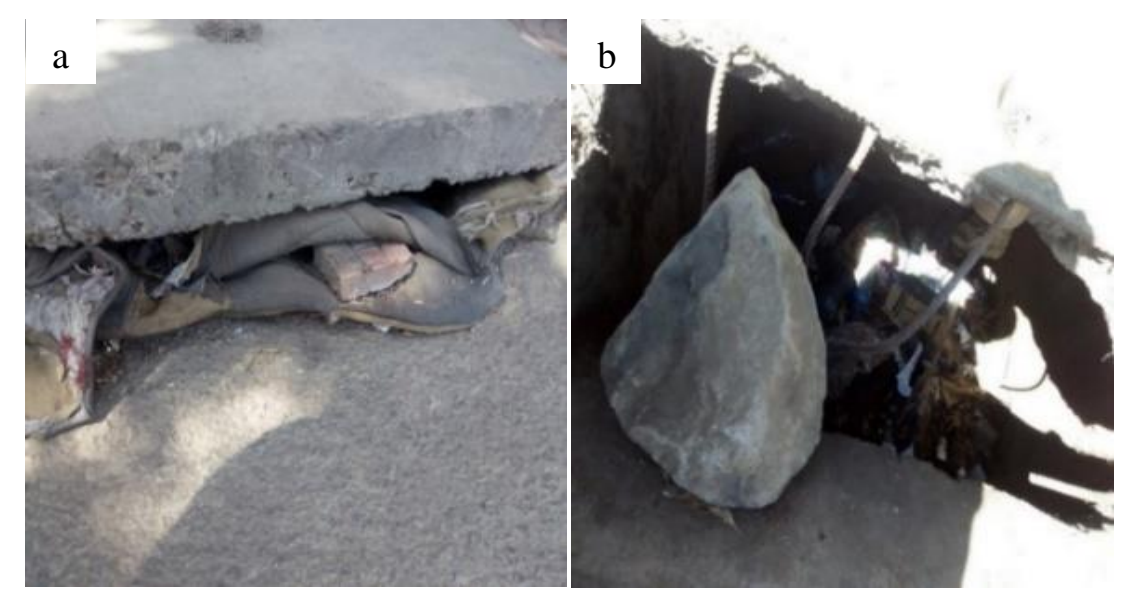

Figure 8. (a) Blocked and damaged manhole; (b) Collection of rubbish upstream of the existing culvert 


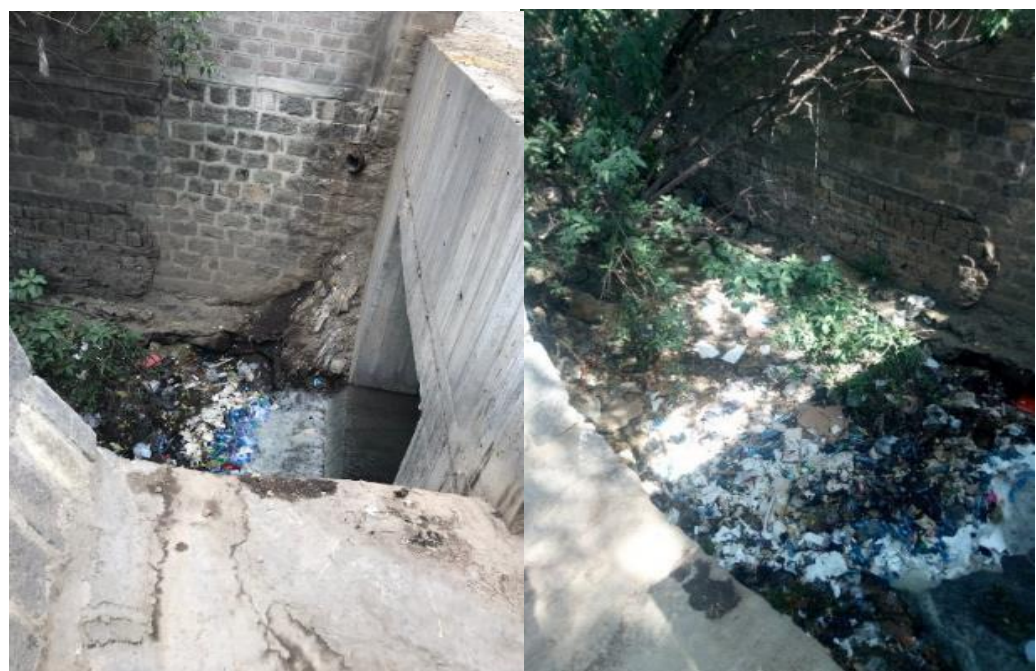

Figure 9. Collection of rubbish downstream of the existing culvert

\subsection{Hydraulic toolbox software result}

Different flow values obtained from rational and HEC HMS were inserted into the Hydraulic toolbox software to obtain design parameters for side drains. Based on the findings from the software, three important things were noticed in consideration of the existing side drains of 900 $\mathrm{mm}$ diameter, these included; some of the side drains were oversized, undersized and others were appropriate. This meant that the appropriate designs could convey the flow without causing any flooding on the infrastructure, the overdesigned drains meant they can convey the flow but the economic aspect was high and the under-designed drains meant that they can't convey the flow hence leading to flooding.

The over-designed drains don't meet the economical aspect though they can convey the designed flow. It becomes clear that a lot of money was incurred during their manufacturing process. Appropriate sizes are suggested for such drains by considering aspects like maintenance of the drains. Side drainage that is not properly designed can cause flooding in the event of a major storm because the effects of the flow will eventually lead to the collapse of infrastructure and trigger various negative impacts.

\section{Conclusion}

This study aimed to carry out a flood analysis and hydraulic competence of existing drainage structures along the AALRT due to the integration of the highway drainage system with that of the newly constructed AALRT. The aim of proper assessment of the existing drainage DOI: https://doi.org/10.7454/jessd.v4i2.1122 
structure makes this study successful in applying hydrological and hydraulic analysis. The existing box culvert which comprised of one barrel was able to convey the design flow of 29.52 $\mathrm{m} 3 / \mathrm{s}$ with a headwater elevation of $2300.94 \mathrm{~m}$. The undersized side drain was redesigned by increasing its diameter to $1200 \mathrm{~mm}$. However, the challenge of flooding still existed especially at Lancha, and this was due to; the presence of accumulated silt within the manholes, debris at the upstream of the cross culvert, and generally poor maintenance techniques.

The proposed measures to curb the challenges mentioned above include a policy on the management of railway drainage assets that need to be developed with a vision to develop a safe, sustainable and resilient drainage system. The goal is to allow water to flow through the rail infrastructure from the point of entry to the point of exit in such a way. These conditions will support earthworks, rails, and structural assets to work optimally. The placement of intermediate culverts before Lancha, regular removal of sludge, filters at the side channel inlets, periodic maintenance of the existing drainage structure, and widening of the pipelines for side drains to about $1200 \mathrm{~mm}$ to facilitate maintenance are further steps to deal with existing barriers.

This study will act as a benchmark for drainage assessment, especially for existing structures. Thus, the results of the study can be used as an indicator to identify the most floodprone areas along the railroad so that appropriate maintenance strategies can be found to overcome these challenges. However, this study had some limitations, like lack of design drawings for the infrastructure understudy, hence making the research to be based on as measured drawings, limited to only flood analysis not flood risk assesment. Future studies could look at handling the aspect of flood risk assessment in depth and also use more than one modeling softwares both for hydraulic and hydrological modeling to compare the output for substantial decision making.

\section{Acknowledgement}

The authors wish to greatly acknowledge World Bank through the African Railway Centre of Excellence, Addis Ababa Institute of Technology, Addis Ababa University for the financial aid that was awarded to the first author. 


\section{Author Contribution}

Conceptualization, M.K.; Methodology, M.K, J.B.N and S.Y.; Software, M.K.; Validation, M.K., J.B.N. and J.W.M.; Formal Analysis, M.K, J.B.N.; Investigation, M.K and S.Y.; Writing - Original Draft Preparation, M.K, J.B.N and J.W.M.; Writing - Review \& Editing, J.B.N and M.K.; Visualization, M.K., J.B.N and J.W.M.; Supervision, M.K.

\section{References}

Adeloye, A. J., \& Rustum, R. (2011). Lagos (Nigeria) flooding and influence of urban planning. Proceedings of the Institution of Civil Engineers-Urban Design and Planning, 164(3), 175-187. https://doi.org/10.1680/udap.1000014

Alamirew, F. (2016). Impacts of informal settlement on environment (the case of Nefas silk Lafto sub city). MA. Thesis, Ethiopian Civil Service University.

Alemu, H. (2017). Investigation of Flooding Problems in Urban Drainage System: the case at Zenebe Werk in Addis Abeba, Ethiopia. Msc. Thesis, Addis Ababa Institute of Technology. http://etd.aau.edu.et/handle/123456789/9741

Amin, M. T., Rizwan, M., \& Alazba, A. A. (2016). A best-fit probability distribution for the estimation of rainfall in northern regions of Pakistan. Open Life Sciences, 11(1), 432440. https://doi.org/10.1515/biol-2016-0057

Arrighi, C., Pregnolato, M., Dawson, R. J., \& Castelli, F. (2019). Preparedness against mobility disruption by floods. Science of the Total Environment, 654, 1010-1022. https://doi.org/10.1016/j.scitotenv.2018.11.191

ARTC. (2013). Engineering Practices manual. Australian Rail Track Corporation LTD

Berndtsson, R., Becker, P., Persson, A., Aspegren, H., Haghighatafshar, S., Jönsson, K., \& Nordström, J. (2019). Drivers of changing urban flood risk: A framework for action. Journal of environmental management, 240, 47-56. https://doi.org/10.1016/j.jenvman.2019.03.094

Chanapathi, T., \& Thatikonda, S. (2020). Investigating the impact of climate and land-use land cover changes on hydrological predictions over the Krishna river basin under present and future scenarios. Science of The Total Environment, 721, 137736. https://doi.org/10.1016/j.scitotenv.2020.137736 
Chow, V. T., Maidment, D. R. \& Mays, L. W. (1988). Applied Hydrology. 1st edition. New York:

Conrad, O., Bechtel, B., Bock, M., Dietrich, H., Fischer, E., Gerlitz, L., Wehberg, J., Wichmann, V., et al. (2015). System for automated geoscientific analyses (SAGA) v.2.1.4. Geoscientific Model Development, 8(7), 1991-2007. https://doi.org/10.5194/gmd-8-1991-2015

Crichton, D. (2008). Role of insurance in reducing flood risk. The Geneva Papers on Risk and Insurance-Issues and Practice, 33(1), 117-132. https://link.springer.com/article/10.1057/palgrave.gpp.2510151

CSA. (2013). Population Projection of Ethiopia for All Regions at Wereda Level from 2014 2017. Addis Ababa: Central Statistical Agency.

Davis, D.W. (2003). Risk analysis in flood damage reduction studies, The corps experience. Proceedings of the Congress of Environmental and Water Resources Institute, Philadelphia, PA, USA, 23-26. https://ascelibrary.org/doi/abs/10.1061/40685(2003)306 EPA. (2003). Protecting water quality from urban runoff. United States Environmental Agency, Washington. Environmental Protection Agency. https://www3.epa.gov/npdes/pubs/nps_urban-facts_final.pdf

ERA. (2013). Drainage Design Manual, Ethiopian Roads Authority. Ethiopian Roads Authority Drainage Design Manual | 123 Help Me. https://www.123helpme.com/essay/Ethiopian-Roads-Authority-Drainage-DesignManual-191258

Gülbaz, S., \& Kazezyılmaz-Alhan, C. M. (2017). An evaluation of hydrologic modeling performance of EPA SWMM for bioretention. Water Science and Technology, 76(11), 3035-3043. https://doi.org/10.2166/wst.2017.464

Hasan, H. H., Mohd Razali, S. F., Ahmad Zaki, A. Z. I., \& Mohamad Hamzah, F. (2019). Integrated Hydrological-Hydraulic Model for Flood Simulation in Tropical Urban Catchment. Sustainability, 11(23), 6700. https://doi.org/10.3390/su11236700

Intergovernmental Panel on Climate Change (IPCC). (2007). Climate Change 2007: Fourth Assessment Report Climate Change 2007 Synthesis Report, Topic3. http://www.ipcc.ch/pdf/assessment-report/ar4/syr/ar4_syr.pdf 
Klijn, F., Samuels, P., \& Van Os, A. (2008). Towards flood risk management in the EU: state of affairs with examples from various European countries. International Journal of River Basin Management, 6(4), 307-321. https://doi.org/10.1080/15715124.2008.9635358

Kumar, M., Kumar, R., Singh, P. K., Singh, M., Yadav, K. K., \& Mittal, H. K. (2015). Catchment delineation and morphometric analysis using geographical information system. Water Science and Technology, 72(7), 1168-1175. https://doi.org/10.2166/wst.2015.303

Morita, M. (2008). Flood risk analysis for determining optimal flood protection levels in urban river management. Journal of Flood Risk Management, 1(3), 142-149. https://doi.org/10.1111/j.1753-318X.2008.00016.x

National Research Council. (2000). Risk Analysis and Uncertainty in Flood Damage Reduction Studies. National Academy Press: Washington, DC, USA, p. 179. https://www.nap.edu/read/9971

Nigussie, M. (2018). Roles and Constraining factors of Women and Children affair's for the advancement of gender mainstreaming and women empowerment: A case study of Nifas Silk - Lafto Sub city, Addis Ababa. MA. Thesis, Addis Ababa university technology, College of Development studies.

Nkwunonwo, U. C., Whitworth, M., \& Baily, B. (2020). A review of the current status of flood modelling for urban flood risk management in the developing countries. Scientific African, 7, e00269. https://doi.org/10.1016/j.sciaf.2020.e00269

Normann, J.M., Houghtalen, R. J., \& Johnston, W. J. (1985). Hydraulic Design of Highway Culverts, Hydraulic Design Series No. 5. Federal Highway Administration. https://rosap.ntl.bts.gov/view/dot/54219

Pregnolato, M., Ford, A., Wilkinson, S. M., \& Dawson, R. J. (2017). The impact of flooding on road transport: A depth disruption function. Transportation research part D: Transport and Environment, 55, 67-81. https://doi.org/10.1016/j.trd.2017.06.020 
Salunkhe, S. S., Rao, S. S., Prabu, I., Venkataraman, V. R., Murthy, Y. K., Sadolikar, C., \& Deshpande, S. (2018). Flood inundation Hazard modelling using CCHE2D hydrodynamic model and geospatial data for embankment breaching scenario of Brahmaputra River in Assam. Journal of the Indian Society of Remote Sensing, 46(6), 915-925. https://doi.org/10.1007/s12524-018-0749-3

Semadeni-Davies, A., Hernebring, C., Svensson, G., \& Gustafsson, L. G. (2008). The Impacts of Climate Change and Urbanisation on Drainage in Helsingborg, Sweden: Suburban Stormwater. Journal of Hydrology, 350(1-2), 114-125.

https://doi.org/10.1016/j.jhydrol.2007.05.028

Sriyana, I., De Gijt, J. G., Parahyangsari, S. K., \& Niyomukiza, J. B. (2020). Watershed Management Index Based on the Village Watershed Model (VWM) Approach towards Sustainability. International Soil and Water Conservation Research. https://doi.org/10.1016/j.iswcr.2020.01.003

Tassew, B. G., Belete, M. A., \& Miegel, K. (2019). Application of HEC-HMS model for flow simulation in the Lake Tana basin: The case of Gilgel Abay catchment, upper Blue Nile basin, Ethiopia. Hydrology, 6(1), 21. https://doi.org/10.3390/hydrology6010021

Teklay, A., Dile, Y. T., Asfaw, D. H., Bayabil, H. K., \& Sisay, K. (2019). Impacts of land surface model and land use data on WRF model simulations of rainfall and temperature over Lake Tana Basin, Ethiopia. Heliyon, 5(9), e02469.

https://doi.org/10.1016/j.heliyon.2019.e02469

Victor, M. (1971). Soil conservation service National Engineering Handbook. US Government printing office.

Wasko, C., \& Sharma, A. (2017). Global assessment of flood and storm extremes with increased temperatures. Scientific reports, 7(1), 1-8. https://www.nature.com/articles/s41598-017-08481-1

Zhu, X., Liu, B., \& Liu, Y. (2020). New Method for Estimating Roughness Coefficient for Debris Flows. Water, 12(9), 2341. https://doi.org/10.3390/w12092341 